\title{
Changes in Respiration and Phonation in Acting Students after training with the Alexander Technique
}

\author{
Mi Geum Lee ${ }^{a}$, Hong Shik Choi ${ }^{b}$, Hyun Mook Choi ${ }^{c}$, Hee Sook Baek ${ }^{c}$, Sung Eun Lim ${ }^{\mathrm{b}}$, Sang Ken Kauh ${ }^{\mathrm{d}}$, Yaelin Choi ${ }^{\mathrm{a}}$ \\ ${ }^{a}$ Department of Speech Language Pathology, Myongji University, Seoul, Korea \\ ${ }^{b}$ Department of Otorhinolaryngology, The Institute of Logopedics \& Phoniatirics, Yonsei University College of Medicine, Seoul, Korea \\ 'Korean Alexander Technique Association, Seoul, Korea \\ ${ }^{d}$ Department of Mechanical and Aerospace Engineering, Seoul National University, Seoul, Korea
}

Correspondence: Yaelin Choi, PhD

Department of Speech Language Pathology,

Myongji University, 34 Geobukgol-ro,

Seodaemun-gu, Seoul 120-728, Korea

Tel: $+82-2-300-0882$

Fax: +82-2-300-1634

E-mail: yaelinchoi@gmail.com

Received: July 5, 2014

Revised: August 14, 2014

Accepted: September 7, 2014

This paper was summarized from the master's thesis of the first author (2014).

\begin{abstract}
Objectives: The Alexander Technique helps respiration and the projection of voice through changes in the location of the head and relaxation of neck muscles. This study provides objective data on changes in respiration and phonation after training with the Alexander Technique. Methods: A total of 8 students majoring in acting ( 4 female, 4 male) were selected to participate in a program under the guidance of an Alexander Technique specialist. In order to objectively compare figures, tests were done on respiratory function, aerodynamic analysis, acoustic analysis, and electroglottography (EGG). GRBAS and KoreanVoice Handicap Index (K-VHI) were also taken and evaluated. Results: In the respiratory function test, the FVC, $F E V_{1}$, and $\mathrm{FEV}_{1} / \mathrm{FVC}$ had no significant differences. In the aerodynamic analysis, the MPT, GR, and VE significantly increased and the MFR, Psub significantly decreased. In the acoustic analysis, the NHR significantly decreased. In the EGG, the CAx and DQx significantly decreased. The GRBAS evaluation showed that the grade significantly decreased and the $\mathrm{K}-\mathrm{VH}$ evaluation showed that the total and the physical area (P) both significantly decreased. Conclusion: This study provides objective and subjective values on voice changes after the Alexander Technique was used for training. The effectiveness of the training technique was verified through objective data showing changes in respiration and phonation.
\end{abstract}

Keywords: Alexander Technique, Respiratory function test, Aerodynamic analysis, Acoustic analysis, Electroglottography, GRBAS, K-VHI
알렉산더 테크닉(Alexander Technique)은 프레드릭 마티아스 알렉산더(Frederick Matthias Alexander)에 의해 개발된 신체에 대 한 진단 및 치료 기술이다(Baek \& Baek, 2004; Kristl, 2001). 알렉산 더는 연극을 하던 중 목소리를 잃게 되자 발성상의 문제점을 스스 로 해결하기 위하여 자신의 몸을 세심하게 관찰하였다. 그 결과 머 리와 목의 위치를 변화하는 동안 자신의 음성과 표정을 방해하는 습관적인 움직임에 대해 중요한 사실을 발견하고 자신의 문제점을 스스로 치유하였다(Jain, Janssen, \& DeCelle, 2004; Kristl, 2001). 그로 인해 알렉산더는 오래된 습관과 관념으로부터 자유로워질 수 있는 방법을 발견하고 성대, 음성, 호흡 등의 증상들이 호전되었으 며 그의 삶에 커다란 변화를 가져오게 되었다(Baek \& Baek, 2004;
Kristl, 2001). 따라서 알렉산더 테크닉은 자신의 몸의 균형과 자세 및 조화로운 사용을 재학습함으로써 비효율적인 나쁜 습관을 인 식하고 스스로 자제할 수 있는 능력의 효율성을 향상시키기 위해 도와주는 방법이다. 즉, 우리의 음성 사용을 효율적이고 융통성 있 게 하기 위해 우리 몸 전체를 효율적이고 편안하게 사용하는 것이 다(Murphy, 2010).

호흡 및 음성 산출에 영향을 줄 수 있는 알렉산더 테크닉 효과에 관한 선행연구를 살펴보면, 알렉산더 테크닉은 일상생활에서 허리 척추주위근육과 복부 사용의 움직임을 촉진함으로써 근육의 새로 운 패턴 사용으로 근육을 단단하고 강하게 만들어 준다. 그로 인해 호기 근육의 기능을 향상시키는 것으로 나타났다(Austin \& Aus- 
ubel, 1992). 또한 머리의 위치와 목 근육의 이완으로 음성 산출에 도움을 준다. 따라서 머리가 척추의 상단에서 균형이 이루어지면서 목 근육은 이완되고 후두는 자연적인 위치에 있게 된다(Murphy, 2010).

발성에 있어서 가장 기초는 호흡이며 음성을 직업적으로 사용해 야 할 필요가 있는 사람들에게는 호흡이 더욱 중요하다(Han \& Jeong, 2002). 직업적 음성 사용자(professional voice user)는 특수 한 호흡, 발성, 공명 기능이 필요하며 배우, 가수, 교사, 판매원, 성직 자, 전화 판매원, 정치가, 방송인 등을 말한다(Boone, McFarlance, Von Berg, \& Zraick, 2010). 직업적 음성 사용자의 경우 자신의 음성 의 질에 대한 높은 요구와 기대를 가지고 있으며 음성 산출과 음성 질의 작은 변화에도 민감하게 반응한다. 그리고 직업적 음성 사용 자에게 나타나는 음성 문제는 자신의 직업과 전반적인 삶의 행복에 나쁜 영향을 준다(Franco \& Andrus, 2007; Schneider \& Sataloff, 2007). 이러한 직업적 음성 사용자 중 연기자에게 있어서 알렉산더 테크닉은 자신의 몸을 자유롭고 편리하게 사용하도록 해 준다. 이 것으로 자유로운 표현이 가능해지고 특히 호흡법을 통한 긴장 완 화에 의해 목소리 조절이 수월해지고 대화를 명확히 하고 강한 소 리를 낼 수 있도록 도와준다. 또한 정신적인 면에서는 공연에서 오 는 긴장을 완화시켜주고, 바른 자세나 움직임의 향상으로 자신감 을 갖게 되며 호흡량의 향상으로 에너지의 효율적인 사용이 가능 해진다(Baek \& Baek, 2004). 또한 직업적 음성 사용자의 치료에 중 요하게 사용되는 접근법은 올바른 자세, 근육 이완, 호흡 지지, 편안 한 발성시작 등이 제시되었으며 실제 임상에서 효과적이라고 보고 하였다(Pyo, 2011). 따라서 배우는 자신의 신체에 대한 생물학적인 지식을 가지고 잘못된 습관을 고쳐야 하며 자연스러운 호흡과 움 직임이 가능하도록 지속적인 훈련이 필요하다(Park, 2010).

국내외의 선행연구들은 직업적 음성 사용자들의 바른 자세를 통 한 올바른 호흡 및 발성에 대한 중요성을 나타내고 있다. 또한 Austin과 Ausubel (1992)은 호흡 근육 기능을 나타내는 최대호기율(peak expiratory flow, $\mathrm{PEF}$ ), 최대환기량(maximal voluntary ventilation, $\mathrm{MVV}$ ), 최대흡기량(maximal inspiratory pressure, MIP), 최대호기 량(maximal expiratory mouth pressure, MEP) 증가를 통해 알렉 산더 테크닉의 효과를 보여주고 있다. 이처럼 알렉산더 테크닉 효 과에 대해 입증된 국외 선행연구들을 통해 최근 국내에서 알렉산 더 테크닉을 훈련한 연기자, 연주자 등을 위한 자세에 대한 연구는 진행되었으나, 음성변화에 대한 연구는 찾을 수가 없었다.

따라서 본 연구는 음성을 전문적으로 사용하는 연기과 학생을 대상으로 알렉산더 테크닉을 훈련한 후 호흡 및 음성 변화를 객관 적 평가가 가능한 검사기기와 GRBAS 척도 및 Korean-Voice Hand- icap Index (K-VHI)를 이용하여 훈련 전·후 음성 측면에서의 차이 를 비교하고자 하였다. 또한 이를 토대로 음성장애 환자들을 대상 으로 알렉산더 테크닉을 훈련한 후의 음성치료 효과에 대한 기초 자료를 제공하고자 한다.

\section{연구 방법}

\section{연구대상}

본 연구 대상은 20-30대 연기과 학생 남자 4 명과 여자 4 명 총 8 명 을 대상으로 하였다. 이는 그룹수업과 개별수업을 병행함으로써 수 업의 효율성을 높이기 위해 인원수를 10 명 이하로 제한하였다(Austin \& Ausubel, 1992). 구체적인 선정기준은 다음과 같다.

대상자는 척추 측만증, 비만(이상적인 몸무게의 $15 \%$ 이상), 1 주 일 동안 $16 \mathrm{~km}$ 이상 운동하는 달리기 선수, 가수, 댄서는 연구대상 에서 제외하였고, 최근 1년 안에 호흡기 및 음성질환을 경험하거나 치료받은 경험이 없는 비흡연자를 최종 연구대상자로 선정하였다 (Austin \& Ausubel 1992) (Table 1).

\section{실험 방법}

본 연구는 2014년 4-5월 OO 병원 이비인후과에서 알렉산더 테 크닉 훈련 전·후음성전문가에 의해 음성평가를 받았으며 사후 음 성평가는 알렉산더 테크닉 전문가가 참여하여 자세 교정 지도하에 시행되었다. 훈련은 미국 American Center for the Alexander Technique (ACAT)에서 3 년 과정을 졸업하고 10 여 년 이상 미국 알렉산 더 테크닉 협회(AmSAT)의 국제 강사 및 한국에서 활동 중인 전문 지도 교사의 지도하에 2014년 4-5월 OO대학교에서 6주 동안 주 1 회 3 시간씩 총 18 시간으로 진행하였다. 자세한 알렉산더 테크닉 프 로그램 예시는 Appendix 1에 제시하였다.

Table 1. Participants' characteristics

\begin{tabular}{lcccccc}
\hline Participant no. & Gender & $\begin{array}{c}\text { Age } \\
\text { (yr) }\end{array}$ & $\begin{array}{c}\text { Height } \\
(\mathrm{cm})\end{array}$ & $\begin{array}{c}\text { Weight } \\
(\mathrm{kg})\end{array}$ & Smoking & $\begin{array}{c}\text { Voice } \\
\text { disorder }\end{array}$ \\
\hline 1 & $\mathrm{M}$ & 19 & 178 & 66 & No & No \\
2 & $\mathrm{M}$ & 23 & 182 & 70 & No & No \\
3 & $\mathrm{M}$ & 31 & 184 & 74 & No & No \\
4 & $\mathrm{M}$ & 18 & 188 & 71 & No & No \\
5 & $\mathrm{~F}$ & 19 & 167 & 55 & No & No \\
6 & $\mathrm{~F}$ & 27 & 161 & 60 & No & No \\
7 & $\mathrm{~F}$ & 22 & 168 & 60 & No & No \\
8 & $\mathrm{~F}$ & 21 & 170 & 58 & No & No \\
Total (N=8) & - & $22.5(4.4)$ & $174(9.5)$ & $64.2(6.9)$ & - & - \\
\hline
\end{tabular}

Values are presented as number or mean (SD). 
폐활량 검사(vital capacity)

폐활량 검사는 호흡능력을 평가하기 위해 폐활량계 microQuark (Cosmed, Italy)를 이용하여 측정하였다. 대상자가 똑바로 선 자세 에서 공기를 모두 내뱉게 하였다. 그 다음 비강을 막은 후 마우스피 스를 입에 물고 편안하게 3회 호흡을 한 후, 이어지는 네 번째 호흡 은 흡기를 통해 공기를 최대한 많이 들이마신 다음 최대한 빠른 속 도로 가능한 폐의 공기를 모두 호기하도록 하였다. 연습을 통해 올 바르게 수행하는 것으로 판단된 경우 연속으로 총 3 회 반복하여 노 력성 폐활량(forced vital capacity, FVC), 1 초간 노력성 호기량(forced expiratory volume at one second, $\left.\mathrm{FEV}_{1}\right), 1$ 초간 노력성 폐활량에 대한 비(1 second forced expiratory volume/ forced vital capacity, $\mathrm{FEV}_{1} / \mathrm{FVC}$ )를 측정하였다. 결과 중 최대치를 분석의 대상으로 하 였다(Choi, 2009; Choi, Kim, Nam, \& Choi, 2007).

\section{공기역학 검사}

최대발성지속시간(maximum phonation time, MPT)

최대발성지속시간은 Phonatory Aerodynamic System (Model 6600; KayPENTAX, Lincoln Park, NJ, USA)을 이용하여 측정하였 다. 편안한 상태에서 평상시 사용하는 음도와 강도를 유지하며 모 음 / 아/를 최대한 길게 발성하여 총 3 회 반복 실시 후 가장 길게 발 성한 결과를 분석의 대상으로 하였다(Choi et al., 2007).

\section{평균호기류율 및 성문하압}

평균호기류율과 성문하압은 Phonatory Aerodynamic System을 이용하여 측정하였다. 직경 $2 \mathrm{~mm}$ 의 구강 내 튜브(intraoral tube) 를 마스크에 끼운 후 기류가 새어나가지 않도록 마스크를 코와 구 강에 완전히 밀착하여 착용하였다. 튜브를 혀 위에 위치시킨 후 평 상시 사용하는 음도와 강도로 /파/를 1 초에 1 회 산출하는 속도로 5 회 산출하였다. 분석은 5 회 반복하여 시작과 끝 구간을 제외하고 중간 3 회의 평균값을 내어 발성 시 성문폐쇄능력의 변화를 반영해 주고성대조절의 능력을 나타내는중요한 변수인 평균호기류율(mean airflow rate, MFR), 평균 성문하압(subglottal pressure, Psub), 성문 저항(glottal resistance, GR), 음성효율(vocal efficiency, VE)을 측 정하였다(Choi et al., 2007; Ko, Choi, Lim, \& Choi, 2012).

\section{음향학 검사}

음향학 검사는 Sound Blaster Audigy 2 ZS를 활용하여 음성녹음 하고 Multi-Speech 소프트프로그램의 Multi-Dimensional Voice Program (MDVP) Model 5105 (KayPENTAX)를 이용하여 음질 을 분석하였다. 소음이 통제된 방에서 편안한 자세로 앉은 상태에
서 대상자의 입으로부터 $10 \mathrm{~cm}$ 떨어진 위치에서 평상시 사용하는 음도와 강도를 유도하기 위해 ' $\mathrm{OOO}$ 입니다. 아-'라고 대상자의 이 름 뒤에 모음 /아/를 5 초간 연장 발성하여 안정된 중간 3 초 구간을 분석하였다(Kim, 2009; Yun \& Kwon, 1998). 이를 통해 측정 요소 중 성대진동의 문제, 편측 혹은 양측 성대 마비, 다른 후두에 문제 가 있는 경우 음질을 평가하는 데 매우 유용한 변수인 기본주파수 (fundamental frequency, $\mathrm{F}_{0}$ ), 주기 간 주파수 변동율(jitter), 주기 간 진폭 변동율(shimmer), 잡음 대 배음비(noise-to-harmonic ratio, NHR)를 분석하였다.

\section{전기성문파형 검사}

전기성문파형 검사는 Lx Speech Studio (Laryngograph Ltd., London, UK)의 Speech Pattern Element Acquisition and Display (SPEAD) 프로그램을 이용하여 측정하였다. 편안한 자세로 앉은 상태에서 EGG 전극(electrode)을 대상자의 갑상연골 양측에 고정 시키고 평상시의 편안한 목소리로「가을」문단을 읽게 하였다. 이 를 통해 발성 시 성대 내전과 접촉을 통해 발성 양상을 알 수 있는 중요한 변수인 평균기본주파수 분포(DFx mean), 평균음성강도 분 포(DAx mean), 평균성문폐쇄율 분포(DQx mean), 주파수 불규칙 성(CFx), 강도 불규칙성(CAx)을 측정하였다(Kim, 1996; Lee et al., 2003).

\section{청지각 평가}

\section{GRBAS}

GRBAS평가는 대상자가 「가을」 문단을 읽는 동안 숙련된 1인의 언어치료사가 복잡한 음질의 특성을 총체적이고 융통성 있게 평가 하기 위해 널리 사용되는 GRBAS scale을 사용하여 음질을 주관적 으로 평가하였다. GRBAS 척도의 등급은 4점 척도 $(0$, 정상; 1 , 경도; 2 , 중등도; 3 , 고도)로 구성되어 있다. 척도의 구분이 명확하지 않을 경우.5까지 세부 분할하여 표시하였다(Choi et al., 2007; Kim, 1996; Pyo et al., 1999).

한국어판음성장애지수(Korean-Voice Handicap Index)

$\mathrm{K}-\mathrm{VHI}$ 평가는 음성장애의 삶의 질을 측정하는 도구로써 대상자 의 주관적인 평가를 실시하였다. 각 영역은 신체적, 기능적, 정서적 영역으로 나누어져 있으며 각 영역당 10 문항씩 총 30 문항으로 구성 되어 있다. 평가범위는 0-4점으로 5점 척도로 구성되어 있다(Yun, Kim, Son, \& Choi, 2008). 


\section{통계분석}

통계분석은 SPSS version 18.0 (SPSS Inc., Chicago, IL, USA) 통 계 프로그램을 이용하였다. 알렉산더 테크닉 활용 전·후의 호흡 및 음성변화를 알아보고자 윌콕슨 부호순위 검정(Wilcoxon signedrank test)을 실시하였다. 통계적 유의 수준은.05로 검정하였다.

\section{연구 결과}

\section{폐활량 검사}

폐활량 검사결과, $\mathrm{FVC}, \mathrm{FEV}_{1}, \mathrm{FEV}_{1} / \mathrm{FVC}$ 는 알렉산더 테크닉 활 용 전에 비하여 활용 후가 증가하는 양상을 보였으나 통계적으로 유의한 차이가 없었다. 또한 성별에 따른 폐활량의 정상수치를 전. 후 비교하고자 하였으며 성별에 따른 $\mathrm{FVC}, \mathrm{FEV}_{1}, \mathrm{FEV}_{1} / \mathrm{FVC}$ 는 통 계적으로 유의한 차이가 없었다(Table 2).

Table 2. Wilcoxon signed-rank test in respiratory function tests before and after training with Alexander Technique

\begin{tabular}{|c|c|c|c|}
\hline \multirow[t]{2}{*}{ Variable } & $\begin{array}{l}\text { Training before } \\
\qquad(\mathrm{N}=8)\end{array}$ & $\begin{array}{l}\text { Training after } \\
\qquad(\mathrm{N}=8)\end{array}$ & \multirow[t]{2}{*}{$p$-value } \\
\hline & Median $(01,03)$ & Median $(01,03)$ & \\
\hline \multicolumn{4}{|l|}{$\mathrm{FVC}(\mathrm{L})$} \\
\hline Male $(\mathrm{N}=4)$ & $5.0(4.0,5.4)$ & $4.9(4.4,5.1)$ & 1.000 \\
\hline Female $(\mathrm{N}=4)$ & $3.6(3.6,3.8)$ & $3.4(3.1,3.7)$ & .197 \\
\hline Total & $3.8(3.6,5.1)$ & $4.0(3.4,5.0)$ & .293 \\
\hline \multicolumn{4}{|l|}{$\mathrm{FEV}_{1}(\mathrm{~L})$} \\
\hline Male (N=4) & $4.2(3.6,4.4)$ & $4.2(4.0,4.3)$ & .715 \\
\hline Female $(\mathrm{N}=4)$ & $3.1(2.7,3.4)$ & $2.9(2.6,3.3)$ & .144 \\
\hline Total & $3.4(2.9,4.2)$ & $3.7(2.8,4.2)$ & .263 \\
\hline \multicolumn{4}{|l|}{$\mathrm{FEV}_{1} / \mathrm{FVC}(\%)$} \\
\hline Male $(\mathrm{N}=4)$ & $86.7(79.0,90.8)$ & $85.8(80.2,96.7)$ & .465 \\
\hline Female $(\mathrm{N}=4)$ & $84.2(72.5,95.5)$ & $89.2(79.7,93.7)$ & .465 \\
\hline Total & $86.7(74.5,93.9)$ & $87.6(80.2,93.7)$ & .327 \\
\hline
\end{tabular}

$01=25$ percentile; $03=75$ percentile; $F V C=$ forced vital capacity; $F E V_{1}=$ forced expiratory volume at one second.

Table 3. Wilcoxon signed-rank test in aerodynamic analysis before and after training with Alexander Technique

\begin{tabular}{lcccc}
\hline \multirow{2}{*}{ Variable } & Training before $(\mathrm{N}=8)$ & & Training after $(\mathrm{N}=8)$ & \\
\cline { 2 - 2 } \cline { 5 - 5 } & Median $(01,03)$ & & Median $(01,03)$ & \\
\cline { 1 - 2 } MPT $(\mathrm{sec})$ & $13.8(12.7,17.2)$ & & $16.2(14.1,23.2)$ & .012 \\
MFR $(\mathrm{L} / \mathrm{sec})$ & $.14(.05, .22)$ & & $.05(.03, .12)$ & .018 \\
Psub $\left(\mathrm{cmH}_{2} \mathrm{O}\right)$ & $6.4(4.9,7.7)$ & & $5.5(4.7,6.4)$ & .036 \\
GR $\left(\mathrm{ds} / \mathrm{cm}^{5}\right)$ & $54.2(26.2,122.4)$ & & $93.0(48.5,175.0)$ & .012 \\
VE $(\mathrm{ppm})$ & $209.5(127.8,563.7)$ & & $878.4(299.7,1520.7)$ & .012 \\
\hline
\end{tabular}

$01=25$ percentile; $03=75$ percentile; $\mathrm{MPT}=$ maximum phonation time; $\mathrm{MFR}=$ mean airflow rate; Psub= subglottal pressure; $G R=$ glottal resistance; $V E=$ vocal efficiency

\section{공기역학 검사}

공기역학 검사 결과, $\mathrm{MPT}, \mathrm{GR}, \mathrm{VE}$ 가 알렉산더 테크닉 활용 전에 비하여 활용 후가 통계적으로 유의하게 증가하였다 $(p<.05)$. 또한 MFR, Psub가 알렉산더 테크닉 활용 전에 비하여 활용 후가 통계적 으로 유의하게 감소하였다 $(p<.05)$ (Table 3).

\section{음향학 검사}

음향학 검사 결과, 변수 중 성별에 따라 영향을 많이 미치는 $\mathrm{F}_{0}$ 는 남녀 각각 통계적으로 분석하고자 하였으며 알렉산더 테크닉 훈련 전·후 성별에 따른 $\mathrm{F}_{0}$ 는 통계적으로 유의한 차이가 없었다(Table 4). 그리고 그 외 변수 중에서는 NHR 이 알렉산더 테크닉 활용 전에 비 하여 활용 후가 통계적으로 유의하게 감소하였다( $p<.05)$ (Table 5).

\section{전기성문파형 검사}

전기성문파형 검사 결과, 변수 중 성별에 따라 영향을 많이 미치 는 $\mathrm{DFx}$ 와 $\mathrm{CFx}$ 는 남녀 각각 통계적으로 분석하고자 하였으며 알렉 산더 테크닉 훈련 전·후 성별에 따른 $\mathrm{DFx}$ 와 $\mathrm{CFx}$ 는 통계적으로 유 의한 차이가 없었다(Table 6). 그리고 그 외 변수 중에서는 CAx, $\mathrm{DQx}$ 가 알렉산더 테크닉 활용 전에 비하여 활용 후가 통계적으로 유의하게 감소하였다 $(p<.05)$ (Table 7).

\section{GRBAS 및 K-VHI}

GRBAS평가 결과, grade가 알렉산더 테크닉 활용 전에 비하여 활용 후가 통계적으로 유의하게 감소하였다 $(p<.05)$ (Table 8). K-

Table 4. Wilcoxon signed-rank test in fundamental frequency $\left(\mathrm{F}_{0}\right)$ before and after training with Alexander Technique

\begin{tabular}{lcccc}
\hline Variable & Training before $(\mathrm{N}=8)$ & & Training after $(\mathrm{N}=8)$ & \\
& Median $(01,03)$ & & Median $(01,03)$ & \\
\hline$F_{0}(\mathrm{~Hz})$ & & & \\
$\quad$ Male $(\mathrm{N}=4)$ & $95.0(92.2,96.4)$ & & $93.6(92.3,95.3)$ & .465 \\
Female $(\mathrm{N}=4)$ & $194.9(190.2,196.7)$ & & $195.9(188.8,201.9)$ & .465 \\
\hline
\end{tabular}

$01=25$ percentile; $03=75$ percentile.

Table 5. Wilcoxon signed-rank test in acoustic analysis before and after training with Alexander Technique

\begin{tabular}{lcccc}
\hline \multirow{2}{*}{ Variable } & Training before $(\mathrm{N}=8)$ & & Training after $(\mathrm{N}=8)$ & \\
\cline { 2 - 2 } & Median $(01,03)$ & & Median $(01,03)$ & \\
Jitter $(\%)$ & $1.10(.49,1.57)$ & & $.63(.50, .93)$ & .050 \\
Shimmer $(\%)$ & $3.00(2.40,3.55)$ & & $2.88(1.82,3.10)$ & .263 \\
NHR & $.13(.12, .13)$ & & $.11(.10, .12)$ & .012 \\
\hline
\end{tabular}

$01=25$ percentile; $03=75$ percentile; NHR= noise-to-harmonic ratio. 
Table 6. Wilcoxon signed-rank test in DFx and CFx before and after training with Alexander Technique

\begin{tabular}{lclll}
\hline \multirow{2}{*}{ Variable } & Training before $(\mathrm{N}=8)$ & & Training after $(\mathrm{N}=8)$ & \\
& Median $(01,03)$ & & Median $(01,03)$ & \\
\hline DFx $(\mathrm{Hz})$ & & & & \\
$\quad$ Male $(\mathrm{N}=4)$ & $101.7(92.0,103.8)$ & & $102.7(95.7,103.6)$ & .715 \\
$\quad$ Female $(\mathrm{N}=4)$ & $194.7(188.2,201.7)$ & & $190.0(181.3,193.0)$ & .144 \\
CFx $(\%)$ & & & \\
$\quad$ Male $(\mathrm{N}=4)$ & $9.8(7.5,13.0)$ & & $7.3(6.5,11.0)$ & .068 \\
Female $(\mathrm{N}=4)$ & $4.6(4.0,9.3)$ & & $6.3(5.4,9.3)$ & .144 \\
\hline
\end{tabular}

$01=25$ percentile; $03=75$ percentile; $D F x=$ frequency distribution; $C F x=$ pitch crossplot irregularity.

Table 7. Wilcoxon signed-rank test in electroglottography before and after training with Alexander Technique

\begin{tabular}{lccccc}
\hline Variable & Training before $(\mathrm{N}=8)$ & & Training after $(\mathrm{N}=8)$ & & p-value \\
\cline { 2 - 2 } \cline { 5 - 5 } & Median $(01,03)$ & & Median $(01,03)$ & \\
\hline $\mathrm{DAx}(\mathrm{dB})$ & $49.1(46.9,51.3)$ & & $48.4(47.2,49.9)$ & .161 \\
$\mathrm{CAx}(\%)$ & $6.1(3.6,11.7)$ & & $4.2(2.8,11.8)$ & .017 \\
$\mathrm{D} 0 x(\%)$ & $46.9(43.5,48.8)$ & & $43.3(40.5,45.3)$ & .025 \\
\hline
\end{tabular}

$01=25$ percentile; $03=75$ percentile; $\mathrm{DAx}=$ amplitude quotient distribution; $\mathrm{CAx}=$ amplitude crossplot irregularity; $\mathrm{DQx}=$ quotient distribution.

$\mathrm{VHI}$ 평가 결과, 총 합계와 신체적 영역(P)이 알렉산더 테크닉 활용 전에 비하여 활용 후가 통계적으로 유의하게 감소하였다 $(p<.05)$

(Table 9).

\section{논의 및 결론}

본 연구는 연기과 학생을 대상으로 알렉산더 테크닉 훈련 전·후 의 호흡 및 음성 특성의 변화를 비교하고자 하였다.

첫째, 폐활량 검사 결과 $\mathrm{FVC}, \mathrm{FEV}_{1}, \mathrm{FEV}_{1} \mathrm{FVC}$ 는 알렉산더 테크 닉 훈련 전에 비하여 훈련 후가 증가하는 양상을 보였으나 통계적으 로는 유의한 차이는 없었다. 한국인의 정상 폐활량 예측 연구(Choi, Baek, \& Lee, 2005)에 의하면, 성별에 따른 폐활량의 정상 수치가 20-29세의 정상 성인 남성의 경우 $\mathrm{FVC}(5.0 \mathrm{~L}), \mathrm{FEV}_{1}(4.42 \mathrm{~L}), \mathrm{FEV}_{1} /$ $\mathrm{FVC}(87.0 \%)$, 정상 성인 여성의 경우 $\mathrm{FVC}(3.5 \mathrm{~L}), \mathrm{FEV}_{1}(3.1 \mathrm{~L}), \mathrm{FEV}_{1} /$ $\mathrm{FVC}$ (88.3\%)이다. 본 연구에서 연기과 학생의 성별에 따른 결과에 서 남녀의 $\mathrm{FVC}, \mathrm{FEV}_{1}, \mathrm{FEV}_{1} / \mathrm{FVC}$ 가 모두 정상 범주에 속하였다.

둘째, MPT는 알렉산더 테크닉 훈련 전에 비하여 훈련 후가 통계 적으로 유의하게 증가하였다 $(p<.05)$. 이는 연기과 학생들의 호흡 기능검사에서 통계적으로 유의한 차이가 없었던 것으로 보아 MPT 증가는 호흡 기능보다 성대수준에서의 호기류의 조절과 관련이 있 다고 할 수 있다. 이는 Choi 등(2007)의 연구에 따라 발성 시에 성문
Table 8. Wilcoxon signed-rank test in GRBAS before and after training with Alexander Technique

\begin{tabular}{lcccc}
\hline \multirow{2}{*}{ Variable } & Training before $(\mathrm{N}=8)$ & & \multicolumn{1}{c}{ Training after $(\mathrm{N}=8)$} & \\
\cline { 2 - 2 } & Median $(01,03)$ & & Median $(01,03)$ & \\
\hline Grade & $.5(.1,1.0)$ & & $.0(.0, .5)$ & .034 \\
Rough & $.0(.0, .5)$ & & $.0(.0, .0)$ & .157 \\
Breathy & $.5(.0,5)$ & & $.0(.0, .3)$ & .083 \\
Asthenic & $.0(.0, .0)$ & & $.0(.0, .0)$ & 1.000 \\
Strained & $.0(.0, .3)$ & & $.0(.0, .0)$ & .157 \\
\hline
\end{tabular}

$01=25$ percentile; $03=75$ percentile.

Table 9. Wilcoxon signed-rank test in K-VHI before and after training with $\mathrm{Al}$ exander Technique

\begin{tabular}{lcccc}
\hline \multirow{2}{*}{ Variable } & Training before $(\mathrm{N}=8)$ & & Training after $(\mathrm{N}=8)$ & \\
\cline { 2 - 2 } \cline { 5 - 5 } & Median $(01,03)$ & & Median $(01,03)$ & \\
\hline Total & $13.0(4.2,19.5)$ & & $7.0(1.5,18.5)$ & .018 \\
P (physical) & $9.5(2.2,12.7)$ & & $5.5(.2,9.2)$ & .011 \\
F (functional) & $2.0(.2,5.0)$ & & $1.5(.2,5.7)$ & .414 \\
E (emotional) & $1.0(.0,4.5)$ & & $.0(.0,4.0)$ & .157 \\
\hline
\end{tabular}

$01=25$ percentile; $03=75$ percentile; $\mathrm{K}-\mathrm{VHI}=$ Korean-Voice Handicap Index.

폐쇄능력의 변화를 반영해주고 성대조절의 능력을 나타내는 MFR, Psub, GR, VE 등과 관련이 있다고 할 수 있으며 DQx 감소로 인해 힘이 덜 들어가는 편안한 발성으로 효율적인 성대접촉을 통해 알 렉산더 테크닉 훈련을 통하여 성대의 벨빙 기능이 향상되었다고 해 석할수 있다.

본 연구에서 MFR, Psub은 알렉산더 테크닉 훈련 전에 비하여 훈련 후가 통계적으로 유의하게 감소하였다 $(p<.05)$. 이는 Psub 감 소, MFR 감소, $\mathrm{VE}$ 증가로 인해 성대 수준에서 더 효과적으로 기류 를 사용한다고 해석할 수 있다. Psub은 성대가 진동하기 전 성대 아 래에서 성대를 움직이기 위해 요구되는 압력을 말하고, MFR은 성 대가 진동할 때 흘러나오는 공기의 흐름을 나타내는 수치이므로 이 둘은 발성에 관여하는 호흡능력을 반영해 준다(Lee, Lee, \& Hwang, 2012). 또한 작은 Psub과 적은 MFR로 큰 음의 강도를 산출할 경우 VE가 높다고 할 수 있다(Kim, 2014). 그러므로 VE 증가로 발성할 때 폐에서 올라온 기류를 한번에 많은 양을 내보내지 않고 효율적 으로 사용한다고 볼 수 있으며 MPT 증가를 설명해 준다고 해석할 수있다.

본 연구에서 GR과 VE가 알렉산더 테크닉 훈련 전에 비하여 훈 련 후가 통계적으로 유의하게 증가하였다 $(p<.05)$. GR은 발성 시 성문 폐쇄력의 변화를 반영하므로 후두 조절 상태를 알아볼 수 있 는 지표로 널리 사용된다(Nam \& Choi, 2007). 또한 본 연구에서 
Psub에 비해 상대적으로 MFR의 수치가 더 크게 감소함으로써 GR 의 수치가 증가한 것으로 해석할 수 있다. 이는 발성할 때 더 효율적 인 기류 사용으로 초당 더 적은 기류를 사용하면서 GR도 높아진 것으로 판단된다.

셋째, 음향학 검사 결과 성별에 따른 $\mathrm{F}_{0}$ 는 남녀 모두 통계적으로 유의한 차이가 없었다. 또한 연기과 학생 전체의 jitter, shimmer는 알렉산더 테크닉 훈련 전에 비하여 훈련 후가 감소하는 양상을 보 였으나 통계적으로 유의한 차이가 없었다. Jitter와 shimmer 모두 값이 커질수록 비주기적인 성대진동이 일어났음을 의미한다(Choi et al., 2007). 그러므로 알렉산더 테크닉을 통해 긴장이 완화되면서 본 연구의 공기역학적 검사 결과와 비교하였을 때 MFR이 낮아지 고 VE가 증가하면서 발성을 더 효율적으로 사용한다는 결과로 생 각할 수 있다. 이는 효율적인 발성으로 성대 진동에 영향을 주면서 jitter와 shimmer 역시 감소하는 결과를 보인 것으로 판단된다.

본 연구에서 NHR은 알렉산더 테크닉 훈련 전에 비하여 훈련 후 가 통계적으로 유의하게 감소하였다 $(p<.05)$. NHR는 음질의 지각 적인 평가와 높은 상관성을 보여주며 성대의 불완전한 내전으로 인 해 거칠고 쉰목소리를 수량적으로 측정하는 데 유용하다(Ko, 2003). 이는 연기과 학생들이 알렉산더 테크닉 훈련 전에 나타난 거칠고 쉰 목소리의 정도가 훈련 후 효율적인 성대 내전과 발성으로 인해 줄어들면서 jitter, shimmer의 감소와 더불어 음질이 개선되었다고 판단된다. 이는 알렉산더 테크닉을 통해 긴장이 완화되면서 발성을 효율적으로 사용하게 되고 이를 통해 음질이 개선되었다고 판단할 수 있다.

넷째, 전기성문파형 검사 결과 성별에 따른 $\mathrm{DFx}$ 와 $\mathrm{CFx}$ 은 남녀 모두 통계적으로 유의한 차이가 없었다. 또한 연기과 전체를 대상 으로 $\mathrm{DAx}$ 는 통계적으로 유의한 차이는 없었으나 $\mathrm{CAx}$ 는 알렉산더 테크닉 훈련 전에 비하여 훈련 후가 통계적으로 유의하게 감소하였 다 $(p<.05)$. 이는 전체적으로 평균 기본주파수와 강도 분포는 큰 변화가 없었으나, 강도 불규칙성이 유의미하게 감소한 것으로 보아 알렉산더 테크닉 훈련을 통하여 음성의 강도를 좀 더 안정적으로 조절해 주는 것으로 보인다.

본 연구에서 $\mathrm{DQx}$ 은 알렉산더 테크닉 훈련 전에 비하여 훈련 후 가 통계적으로 유의하게 감소하였다 $(p<.05)$. 이는 연기과 학생들이 알렉산더 테크닉 훈련 전에는 성대에 약간의 힘을 주어 발성하는 양상을 보였으나, 훈련 후에는 이완이 되면서 힘이 덜 들어가는 편 안한 발성으로 성문폐쇄율이 낮은 경향을 보이는 것으로 판단된다.

다섯째, GRBAS 평가 결과 grade가 알렉산더 테크닉 훈련 전에 비하여 훈련 후가 통계적으로 유의하게 감소하였다 $(p<.05)$. 또한 대상자의 특성을 보았을 때 rough, breathy, strained가 통계적으로
유의한차이는 없었으나, 알렉산더 테크닉 훈련 전에 비해서 훈련 후 가 감소하는 양상을 보였다. 이는 효율적인 발성으로 인해 연기과 학생들이 알렉산더 테크닉 훈련 전에 나타났던 거칠거나 쉰 소리, 긴장해서 발성했던 양상이 효과적으로 줄어든 것으로 판단된다.

본 연구에서 $\mathrm{K}-\mathrm{VHI}$ 평가 결과 총 합계와 신체적 영역 $(\mathrm{P})$ 이 알렉 산더 테크닉 훈련 전에 비하여 훈련 후가 통계적으로 유의하게 감 소하였다 $(p<.05) . \mathrm{K}-\mathrm{VHI}$ 의 신체적인 영역의 문항은 타인이 느끼 는 자신의 음성변화가 아닌 본인이 직접 신체적으로 음성 변화를 느끼는 정도를 평가하는 것이다. 이는 알렉산더 테크닉 훈련 후에 대상자가 직접 신체적인 변화를 더 많이 느끼는 것으로 해석할 수 있으며, 타인에 의한 것보다 대상자가 직접적으로 느끼는 본인의 만 족도가 비교적 높은 것으로 판단된다.

본 연구는 알렉산더 테크닉을 훈련한 후 음성변화에 대한 객관 적 및 주관적인 수치를 국내외에서 처음 제시함으로써 알렉산더 테크닉을 통한 호흡 및 음성 변화에 효과가 있음을 객관적인 자료 로 제시하였다는 점에 의의가 있다.

본 연구의 제한점과 후속연구를 위한 제언으로는 대상자 8 명을 대상으로 하여 연구 결과가 전체 집단을 대표할 수 없고, 성별에 따 른 신장, 체중을 통제하지 못하였다. 또한 총 6 회기 18 시간의 프로 그램으로 진행되었으나, 후속 연구에서는 대상자에 따라 치료 회기 를 고려하여 연구가 이루어져야 할 것이다. 추후 연구에서는 이들 을 보완하여 알렉산더 테크닉 효과를 더 명확히 밝힐 필요가 있다.

\section{REFERENCES}

Austin, J. H., \& Ausubel, P. (1992). Enhanced respiratory muscular function in normal adults after lessons in proprioceptive musculoskeletal education without exercises. Chest, 102, 486-490.

Baek, H. S., \& Baek, H. S. (2004). Alexander Technique. Seoul: Naturomedica. Boone, D. R., McFarlane, S. C., Von Berg, S. L., \& Zraick, R. I. (2010). The voice and voice therapy (8th Ed.). Boston, MA: Allyn \& Bacon.

Choi, J. K., Paek, D. M., \& Lee, J. O. (2005). Normal predictive values of spirometry in Korean population. Tuberculosis and Respiratory Diseases (Seoul), $58,230-242$

Choi, J. N., Kim, H. H., Nam, J. M., \& Choi, H. S. (2007). Characteristics of glottal area waveform and phonation in patients with unilateral vocal fold palsy or sulcus vocalis. Korean Journal of Communication Disorders, 12, 487-507.

Choi, Y. (2009). Breathing characteristics of adults with unilateral vocal fold palsy. Korean Journal of Communication Disorders, 14, 212-222. 
Franco, R. A., \& Andrus, J. G. (2007). Common diagnoses and treatments in professional voice users. Otolaryngologic Clinics of North America, 40, 1025 1061.

Han, J. Y., \& Jeong, O. R. (2002). Voice intervention of professional voice users with a holistic voice management program. Journal of Speech \& Hearing Disorders, 11, 141-174.

Jain, S., Janssen, K., \& DeCelle, S. (2004). Alexander technique and Feldenkrais method: a critical overview. Physical Medicine and Rehabilitation Clinics of North America, 15, 811-825.

Kim, H. H. (1996). Perceptual, acoustical, and physiological tools in ataxic dysarthria management: a case report. Proceedings of the 2nd Korean Society of Phonetic Sciences and Speech Technology Semiannual Conference, 9-22.

Kim, J. O. (2009). Acoustic characteristics of the voices of Korean normal adults by gender on MDVP. J Phonetics and Speech Sciences, 1, 147-157.

Kim, J. O. (2014). Korean adult normative data for the KayPENTAX Phonatory Aerodynamic System Model 6600. Phonetics and Speech Sciences, 6, 105-117.

Ko, D. H. (2003). A Study of Extracting Acoustic Parameters for Individual Speakers. Speech Science, 10, 129-143.

Ko, H. J., Choi, H. S., Lim, S. E., \& Choi, Y. L. (2012). The aspect of voice characteristics change after botulinum toxin-a injection in patients with adductor spasmodic dysphonia according to vocal tremor. J Korean Soc Speech Sci, 4, 95-107.

Kristl, M. (2001). The Alexander Technique as a management tool of a connective tissue disorder. Journal of Bodywork and Movement Therapies, 5, 181-190.

Lee, I. A., Lee, H. E., \& Hwang, Y. J. (2012). The study of breath competence depending on utterance condition by healthy speakers: a preliminary study. J Korean Soc Speech Sci, 4, 115-120.

Lee, S. E., Lim, S. E., Choi, S. H., Pyo, H. Y., Choi, J. N., \& Choi, H. S. (2003). The analysis of electroglottographic measures from Lx speech studio program in patients with vocal nodules. J Korean Soc Logoped Phoniatr, 14, 104-109.

Murphy, D. R. (2010). The Alexander Technique in the Choral Classroom (Master's thesis). University of Wisconsin, Platteville, WI.

Nam, D. H., \& Choi, H. S. (2007). Respiration and vocalization. Seoul: koonja publisher.

Park, H. S. (2010). A Study on effective physical training teaching method of actor by Alexander Technique (Master's thesis). Chung-Ang University, Seoul, Korea.

Pyo, H. Y. (2011). A qualitative study on voice therapy for professional voice users. Korean Journal of Communication Disorders, 16, 437-448.

Pyo, H. Y., Choi, S. H., Lim, S. E., Sim, H. S., Choi, H. S., \& Kim, K. M. (1999). The Correlation between GRBAS Scales and MDVP Parameters on the Pathologic Voices of the Patients with Vocal Polyps. J Korean Soc Logoped Phoniatr, 10, 154-163.

Schneider, S. L., \& Sataloff, R. T. (2007). Voice Therapy for the Professional Voice. Otolaryngol Clin North Am, 40, 1133-1149.

Yun, S. Y., \& Kwon, D. H. (1998). Acoustic characteristics of normal children's voice of 5 to 11 years old. Journal of speech \& hearing disorders, 7, 67-78.

Yun, Y. S., Kim, H. H., Son, Y. I., \& Choi, H. S. (2008). Validation of the Korean Voice Handicap Index (K-VHI) and the Clinical Usefulness of Korean VHI-10. Korean Journal of Communication Disorders, 13, 216-238. 
Mi Geum Lee, et al. • Respiration and Phonation after Training the Alexander Technique

Appendix 1. 알렉산더 테크닉 프로그램

\begin{tabular}{|c|c|}
\hline 회기 수 & 프로그램 내용 \\
\hline 1주(1, 2, 3) & $\begin{array}{l}\text { 1) 알렉산더 테크닉의 이해: 기본적인 원리에 대한 설명 } \\
\text { 2) 그라운딩 기술을 통해 서기 } \\
\text { 3) Semi-supine 자세: 자연스러운 호흡 및 발성 } \\
\text { 4) 지시어 }\end{array}$ \\
\hline 2주(4, 5, 6) & $\begin{array}{l}\text { 1) 서기 및 Semi-supine 자세: 지시어를 통해 이완되고 자연스러운 몸의 흐름과 호흡에 대해 각자 느낀 점 말하기 } \\
\text { 2) 중추조절을 통해 앉기 } \\
\text { 3) 상대방의 호흡에 대해 관찰하고 설명 } \\
\text { : Semi-supine 자세 및 앉은 상태에서 'Whisper ah'를 통한 몸의 이완을 느끼기 } \\
\text { : 늑골의 움직임을 느끼며 호흡을 훈련 }\end{array}$ \\
\hline 3주(7, 8, 9) & $\begin{array}{l}\text { 1) Semi-supine 자세 } \\
\text { : 지시어를 의식하면서 'Whisper ah'를 통한 호흡 } \\
\text { : '아, 에, 이, 오, 우' 발성 } \\
\text { 2) 다양한 자세에서 자연스러운 움직임을 느끼고 긴장할 때와 이완될 때의 차이점을 느끼기 } \\
\text { 3) 어깨, 고관절 이완 } \\
\text { 4) 앉기: 호흡 및 발성 }\end{array}$ \\
\hline 4주(10, 11, 12) & $\begin{array}{l}\text { 1) 앉기, 서기, Semi-supine 자세 } \\
\text { : 지시어를 의식하면서 호흡 } \\
: \text { 아, 에, 이, 오, 우 발성 } \\
\text { 2) 읽기 } \\
\text { : 평상시 습관대로 읽는 경우와 바른 자세에서 읽는 경우를 비교 } \\
\text { : 상대방의 모습을 관찰하고 피드백하기 } \\
\text { 3) 바르지 않은 자세에 대한 습관 자제하기 }\end{array}$ \\
\hline 5주(13, 14, 15) & $\begin{array}{l}\text { 1) 앉기, 서기, Semi-supine 자세 } \\
\text { : 지시어를 의식하면서 호흡 } \\
\text { : '아, 에, 이, 오, 우', ‘숫자세기', '안녕하세요. 제 이름은 OOO입니다.' 등 발성 } \\
\text { 2) 목 주위 근육 이완 }\end{array}$ \\
\hline 6주(16, 17, 18) & $\begin{array}{l}\text { 1) 이전까지 배운 자세 복습 } \\
\text { 2) 호흡 및 발성 훈련 }\end{array}$ \\
\hline
\end{tabular}




\section{국문초록}

\section{연기과 학생의 알렉산더 테크닉 훈련 전·후 호흡 및 발성 특성 변화 비교}

이미금 1 최홍식 $\cdot$ 최현묵 ${ }^{3} \cdot$ 백희숙 ${ }^{3} \cdot$ 임성은 $^{2} \cdot$ 고상근 $^{4} \cdot$ 최예린 ${ }^{1}$

1명지대학교 언어치료학과, ${ }^{2}$ 연세대학교 의과대학 이비인후과학교실, 음성언어의학연구소, ${ }^{3}$ 한국 알렉산더 테크닉 협회, ${ }^{4}$ 서울대학교 기계항공공학부

배경 및 목적: 알렉산더 테크닉은 머리의 위치와 목 근육의 이완으로 호흡 및 음성 산출에 도움을 준다. 본 연구의 목적은 음성을 전문 적으로 사용하는 연기과 학생을 대상으로 알렉산더 테크닉 훈련 전. 후의 호흡 및 발성 특성의 변화를 알아보고자 하였다. 방법: 연기 과 학생 남자 4 명과 여자 4 명을 대상으로 알렉산더 테크닉 전문 지도교사의 지도하에 프로그램에 참여하도록 하였다. 알렉산더 테크닉 훈련 전·후 호흡 및 발성 특성의 변화를 비교하기 위해 음성평가는 호흡기능검사, 공기역학 검사, 음향학 검사, 전기성문파형 검사, GRBAS, K-VHI를 시행하였다. 결과: 호흡기능검사에서는 FVC, FEV1, FEV1/FVC은 유의한 차이가 없었다. 공기역학 검사에서는 $\mathrm{MPT}, \mathrm{GR}, \mathrm{VE}$ 가 유의하게 증가하였으며 MFR, Psub 는 유의하게 감소하였다. 음향학 검사에서는 NHR 이 유의하게 감소하였다. 전기 성문파형 검사에서는 $\mathrm{CAx}, \mathrm{DQx}$ 가 유의하게 감소하였다. GRBAS 척도에 대한 평가에서는 $\mathrm{G}$ 척도가, $\mathrm{K}-\mathrm{VHI}$ 를 이용한 평가에서는 총 합계와 신체적 영역 점수가 유의하게 감소하였다. 논의 및 결론: 본 연구는 알렉산더 테크닉을 훈련 한 후 음성변화에 대한 객관적 및 주관적인 수치를 국내·외에서 처음 제시함으로써 알렉산더 테크닉을 통한 훈련이 호흡 및 음성 변화에 효과가 있음을 객관적인 자료 로 제시하였다는 점에 의의가 있다.

핵심어: 알렉산더 테크닉, 호흡기능 검사, 공기역학 검사, 음향학 검사, 전기성문파형 검사, GRBAS, K-VHI

본 논문은 제 1 저자의 석사학위논문(2014)을 요약한 것임.

\section{참고문헌}

고도흥(2003). 개별화자의 음성파라미터 추출에 관한 연구: 음성파라미터 관계를 중심으로. 음성과학, 10, 129-143.

고혜주, 최홍식, 임성은, 최예린(2012). 음성진전 유무에 따른 내전형 연축성 발성장애의 보툴리늄 독소-A 주입 후 음성 특성 변화 양상. 말소리와 음 성과학, 4, 95-107.

김재옥(2009). 성별에 따른 한국 정상 성인 음성의 음향학적 평가 기준치. 말소리와음성과학, 1, 147-157.

김재옥(2014). KayPENTAX Phonatory Aerodynamic System Model 6600을 이용한 한국 성인의 공기역학적 변수들의 정상치. 말소리와 음성과학, 6, 105-117.

김향희(1996). 운동실조형 마비성구음장애에 적용되는 지각적, 음향학적, 생리학적 도구에 관하여. 대한음성학회 2월 학술대회지, 9-22.

남도현, 최홍식(2007). 호흡과 발성. 서울: 군자출판사.

박현심(2010). 알렉산더 테크닉을 활용한 효과적인 배우의 신체훈련 지도법에 관한 연구. 중앙대학교 예술대학원 석사학위논문.

백희숙, 백현숙(2004). 알렉산더 테크닉. 서울: 네츄로메디카.

윤선영, 권도하(1998). 5-11세 아동 음성의 음향학적 특성. 언어치료연구, 7, 67-78.

윤영선, 김향희, 손영익, 최홍식(2008). 한국어판 음성장애지수(Voice Handicap Index, VHI)의 타당도 및 VHI-10의 임상적 유용성. 언어청각장애연

구, 13, 216-238.

이성은, 임성은, 최성의, 표화영, 최재남, 최홍식(2003). Lx Speech Studio를 이용한 성대결절환자의 전기성문파형 측정치 분석. 대한음성언어의학회 지, 14, 104-109.

이인애, 이혜은, 황영진(2012). 발화조건에 따른 정상 성인의 호흡 능력 차이 비교: 예비연구. 말소리와음성과학, 4, 115-120.

최예린(2009). 정상인과 일측성 성대마비환자의 읽기 시 호흡특성 비교. 언어청각장애연구, 14, 212-222.

최재남, 김향희, 남정모, 최홍식(2007). 일측성 성대마비와 성대구증의 성문면적파형과 발성 특성 비교. 언어청각장애연구, 12, 487-507. 
Mi Geum Lee, et al. • Respiration and Phonation after Training the Alexander Technique

최정근, 백도명, 이정오(2005). 한국인의 정상 폐활량 예측치. Tuberculosis and Respiratory Diseases (Seoul), 58, 230-242.

표화영(2011). 직업적 음성사용인의 음성에 대한 질적 연구(2): 음성치료. 언어청각장애연구, 16, 437-448.

표화영, 최성희, 임성은, 심현섭, 최홍식, 김광문(1999). 성대 폴립 환자를 대상으로 한 GRBAS 척도와 MDVP 측정치 간의 상관관계 연구. 대한음성언

어의학지, 10, 154-163.

한지용, 정옥란(2002). 총체적 음성관리 프로그램을 통한 직업적 음성사용자의 음성중재. 한국언어치료학회, 11, 141-174. 